\title{
LABOUR SAFETY OF MEDICAL WORKERS DURING THE COVID-19 PANDEMIC: LEGAL ASPECT
}

DOI: 10.36740/WLek202012202

\author{
Yuriy V. Baulin', Borys A. Rohozhyn², Inna A. Vyshnevska' \\ 'YAROSLAV MUDRYI NATIONAL LAW UNIVERSITY, KHARKIV, UKRAINE \\ 2KHARKIV MEDICAL ACADEMY OF POSTGRADUATE EDUCATION OF THE MINISTRY OF HEALTH OF UKRAINE, KHARKIV, UKRAINE
}

\begin{abstract}
The aim: To develop an algorithm of legal support of the system that guarantees safe working conditions of medical workers at medical institutions during the COVID-19 outbreak. Materials and methods: The following materials were used in the paper: Interim Recommendations of the World Health Organization, documents of The World Medical Association, international human rights instruments, international labour protection acts, European health legislation, the decision of the European Court of Human Rights, judicial practice and survey of 60 specialists. The following methods were used in the paper: system method, comparative method, the method of questionnaires and formal logical method.

Results: The survey of physicians allowed to state the need to create local protocols or technological maps of the use of personal protective equipment and the development and approval of the relevant results of their use - standards to ensure safe working conditions.

Conclusions: Proposals for legal support of the system of guaranteeing safe working conditions for medical workers at the local level have been formulated. Every medical enterprise should have a system of guaranteeing safe working conditions for medical workers by: distribution of responsibilities between the heads of medical enterprises, issuing departmental and local acts on ensuring their work and acquainting medical workers with them, ensuring proper quality and quantity of personal protective equipment and, accordingly, monitoring their use and the functioning of the system of guaranteeing safe conditions.
\end{abstract}

KEY WORDS: Employee Health, means of protection, pandemics

Wiad Lek. 2020;73(12 p. II):2709-2714

\section{INTRODUCTION}

The issue of labour safety is a priority in any area of social life, particularly in the field of medical services. During the COVID-19 pandemic, about a third of the total number of infected people are health workers who come into direct contact with patients. Thus, the International Council of Nurses stated that currently about 230,000 health workers in the world are infected with coronavirus and this number, in their opinion, is underestimated [1]. At the same time, 9,684 (as of August 16) [2] health workers were infected in Ukraine, 30,000 in Italy [3], and 51,849 in Spain [4] (as of July 29).

COVID-19 has become a serious challenge for countries' health care systems. It is the medical workers who have to face the risk of infection every day due to lack of personal protective equipment (hereinafter - PPE) for staff, lack of manpower, lack of effective mechanism for medical staff protection from the risk of infection, etc. [5, p. 740].

This paper is devoted to identifying problematic issues (gaps) in the legal regulation of labour safety system in health care facilities. The survey revealed legal problems that arise in the field of labour safety of health workers during the COVID-19 pandemic.

\section{THE AIM}

To develop an algorithm of legal support of the system that guarantees safe working conditions of medical workers at medical institutions during the COVID-19 outbreak.

\section{MATERIALS AND METHODS}

The following materials were used in the paper: Interim Recommendations of the World Health Organization (hereinafter - WHO), (Interim Recommendation "Infection prevention and control during health care when coronavirus disease (COVID-19) is suspected or confirmed" as of January 25, 2020 [6] and an interim recommendation "Rational use of personal protective equipment for coronavirus disease (COVID-19) and considerations during severe shortages" as of April 6, 2020 [7]), documents of The World Medical Association (Declaration of Geneva [8], International Code of Medical Ethics [9]), international human rights instruments (Universal Declaration of Human Rights [10], International Covenant on Economic, Social and Cultural Rights [11], Convention on Human Rights and Fundamental Freedoms [12]), international labour protection acts (International Labour Organization Convention №155 on Occupational Safety and Health and the Working Environment [13], Council Directive № 89/391/EEC on the introduction of measures to encourage improvements in the safety and health of workers at work [14]), European health legislation (UK, Poland, Ukraine, Germany), the decision of the European Court of Human Rights (Brincat and others v. Malta, Vilnes and Others v. Norway), judicial practice (decisions of courts of France, Russia), survey of 60 specialists.

The following methods were used in the paper: system method (study of the right of a health worker to refuse to perform professional duties as a component of the human 
right to safe working conditions), comparative method (comparison of legal regulation of labour safety and responsibility for failure to meet labour safety requirements), the method of questionnaires (establishing both the level of their legal protection and safety of their activities, and the level of provision of PPE in the provision of medical care to patients, as well as whether there are local acts on these issues in the institutions where they work) and formal logical method (using analysis, synthesis, induction and deduction, the main conclusions of the paper were made).

\section{RESULTS AND DISCUSSION}

Most European countries have faced the problem of mass infection of health workers. Analysis of international organizations and individual countries statistics on the incidence of COVID-19 allows us to conclude that it is necessary to improve the labour safety of health workers in the medical institutions and provide PPE of appropriate quality and in the required quantity.

The basis of the legal regulation of the medical workers' labour safety is the right of a person to appropriate working conditions, an integral part of which is the right to require the employer to create safe working conditions and minimize the risk to life and health of the employee. This right is provided by international acts, such as the International Labour Organization Convention 155 on Occupational Safety and Health and the Working Environment [13] (hereinafter - ILO), the main purpose of which is to prevent accidents and injuries resulting from work (Part 2 of Article 4 of the Convention), and by national law.

In the practice of the ECtHR, the court considers violations of labour safety requirements through the prism of Art. 2 (right to life) and Art. 8 (right to respect for private and family life) of the Convention for the Protection of Human Rights and Fundamental Freedoms. Thus, the Court found a violation of these articles by the employer's failure to notify the employee of the negative impact of work activities on their health, which led to the death of a person (see judgment Brincat and others $v$. Malta) [16]. The Court later ruled that the fact that employees do not have access to labour safety documentation violated Art. 8 of the Convention, according to which they could assess the potential negative risks to their health (see judgment Vilnes and Others v. Norway) [17].

At the same time, the employer is obliged to provide the employee with safe working conditions. According to Art. 16 of the ILO Convention 155 and Art. 5 and 6 of Council Directive № 89/391/EEC on the introduction of measures to encourage improvements in the safety and health of workers at work, the employer must take measures to protect workers, provide appropriate training and provide the necessary means of protection [14].

Relevant provisions are reflected in the regulations of individual states. Thus, according to Art. 8 of the Law of Ukraine "On labour protection", the employer is obliged to provide employees with special clothing, footwear, detergents and other PPE free of charge [18]. A similar rule related to the provision of medical care is provided in Art. 11 of the Polish Law on Prevention and Control of Infections and Infectious Diseases of People. It obliges employers to take preventive measures aimed at minimizing the risk of infection of health workers by monitoring their health, ensuring the use of individual and collective remedies [19].

One of the tools to protect workers' rights to safe working conditions is the employer's liability for failure to comply with these requirements. Thus, in accordance with Art. 160, 165 and 220 of the Polish Penal Code in cases of violation of labour safety, which led or may lead to a threat to life and health of the employee, the employer may be sentenced to imprisonment [20]. In Ukraine, an employer can also be prosecuted for violating labour safety rules according to Article 271 of the Criminal Code, if such an act caused harm to the health of the employee or their death [21]. In this case, the guilty person may be sentenced to a fine or imprisonment.

The Court of Cassation of Francel the French Republic in decision №17-18712 of 11.10.2018 found the employer guilty that he, knowing about the dangerous conditions and potential risks to life and health of the employee, did not take all necessary measures to prevent the occurrence of negative consequences, as a result of which the worker died of an industrial injury. The employer was sentenced to negligent homicide committed during the employee's work [22].

Ensuring safe working conditions is a necessary condition for a medical worker to perform their professional duties. It is known that the general professional duty of a healthcare worker is to provide qualified and qualitative medical care to the patient. This duty is fundamental to conduct medical practice as a whole (see Declaration of Geneva, paragraph 3 of the International Code of Medical Ethics) [23, p. 1840].

At the same time, in carrying out a professional activity, a health worker is said to have the right to appropriate working conditions that meet safety requirements (Article 23, paragraph 1, of the Universal Declaration of Human Rights [10] and Article 7, b, of the International Covenant on Economic, Social and Cultural Rights [11]). In cases where such conditions were not provided in accordance with Art. 13 of the ILOConvention 155 , the employee has the right to refuse to perform their professional duties [13]. This provision is reflected in Article 153 of the Labour Code of Ukraine, according to which in cases where there is a danger to life and health of the employee, they have the right to refuse to perform professional duties [24]. Such cases also occurred during the COVID-19 pandemic.

Thus, on April 7, 2020, in Greece, doctors and medical workers went on strike, during which they came out with demands to increase the number of doctors, places in intensive care units and provide PPE of better quality [25].

A similar case took place in Kharkiv, when on May 18, 2020, doctors of the Centre for Emergency Care and Disaster Medicine refused to perform their professional duties in providing medical care and used their right to strike due to the fact that they did not have the opportunity to use PPE due to its lack, as a result of which they are forced to reuse the same tool [26].

It should be noted that if the employer did not provide safe working conditions (for example, did not provide PPE), the liability of the health worker for failure to provide medical care to a person or improper performance of professional duties is excluded because there is a circumstance that excludes liability for inaction of the health worker. Such circumstance is the lack of a real opportunity to provide medical care without endangering one's own life and health. 
The verdict of the Industrial District Court of Kursk of the Russian Federation recognized the actions of the employer who did not provide the PPE to the employee as a violation of the person's right to safe work, so the latter refused to perform their professional duties. By court decision, the employer was obliged to pay the employee wages for the time during which they did not work, and to pay moral compensation [27].

In return, if a healthcare worker was provided with safe working conditions and PPE, the necessary measures (instruction) were taken to familiarize them with the rules of their application, etc., but they did not fulfil their professional duties, which caused harm to the patient's life and health, the healthcare worker is subject to disciplinary action, even criminal liability for failure to provide medical care (Article 139 of the Criminal Code of Ukraine) or failure to perform or improper performance of professional duties (Article 140 of the Criminal Code of Ukraine).

Thus, in order to increase the effectiveness of the life and health protection of health workers working during the COVID-19 epidemic and to ensure the conditions for them to perform their professional duties, a system to ensure their safe working conditions must function. Such system has the following components:

- scientifically substantiated requirements for PPE and the existence of appropriate rules for its application;

- doctors and medical staff must be familiar with these rules;

- the presence of PPE of appropriate quality and in the required quantity;

- system of control over the use of PPE and other safety equipment both at the medical institution as a whole and at the individual workplace of the medical worker.

Elements of this system should be reflected in every health care institution in the relevant local legal acts on labour safety of health workers, rules for the application of PPE and other safety measures.

Based on studies of the way of infection and symptoms of COVID-19 and the dynamics of its spreading, the WHO has developed a temporary recommendation "Rational use of personal protective equipment for coronavirus disease (COVID-19) and considerations during severe shortages" as of April 6, 2020. It regulates the use of each type of PPE in a specific situation (when examining patients, during resuscitation, in an ambulance, etc.) [14].

Taking into account these recommendations of the $\mathrm{WHO}$, the order of the Ministry of Health of Ukraine № 552 of 25.02.2020 approved the Standard of medical care "Coronavirus disease 2019", which provides not only the prevention, diagnosis and treatment of the disease, but also the responsibilities of the parties in area of labour safety, including the use of PPE [28]. Based on the WHO recommendations and the specified standard, local rules for the use of PPE should be developed in medical institutions. Not only the type of PPE should be estimated, but also the number of PPE required for a medical worker in the performance of their professional duties.

After approval of such rules at the local level, the employer must familiarize medical workers with them and ensure the availability of PPE of appropriate quality and in the appropriate quantity. Section 4 of the WHO Interim Recommendation "Infection prevention and control during health care when coronavirus disease (COVID-19)is suspected or confirmed" as of January 25, 2020, provides the employer's responsibility to train health workers in the care and treatment of patients and the use of PPE during the provision of medical care to patients with COVID-19, to ensure the supply of PPE in sufficient quantities and control its use by health workers [6].

In turn, if PPE is available and provided in sufficient quantities, Section 3 of the WHO Interim Recommendation requires the health worker to use PPE during the provision of medical care and other professional responsibilities.

In particular, paragraph 15 of the Law of Germany on the implementation of labour safety measures to improve the safety and health of workers at work provides for the obligation of the employee to take care of their own safety and health and follow the relevant local instructions of the employer, including use of PPE and other protective devices [29]. Similarly, Article 7 of the UK Occupational Safety and Health Act obliges the employee to take care of their own health and the safety of others and to comply with the labour safety and health requirements set by the employer and provided by the relevant legislation [30].

The WHO acts pay close attention to the administrative control to be exercised by the employer in the form of ensuring the operation of the patient sorting system to reduce the burden on healthcare workers, the organization of the process of surveillance for acute respiratory infections that can be caused by $\mathrm{nCoV}$ among healthcare workers and monitoring their observance of standard precautionary measures and their improvement if necessary.

Therefore, the requirements for PPE, its quantity, quality, rules of application and control over their use by health workers, which are regulated at the international and national levels, should be detailed at the level of the health care institution, which will minimize the risk of infection of healthcare workers with COVID-19 and the cause of harm to their life and health.

In order to establish the state of awareness of health workers in matters of legal protection of their safety, particularly related to the current legal regulations governing the safety of health workers during the COVID-19 outbreak, a survey among the doctors was conducted.

The questionnaire was anonymous, and the sample among medical doctors was random. The survey was remote; respondents were selected on the basis of databases of relevant clinical departments of the Kharkiv Medical Academy of Postgraduate Education. The requirement to participate in the survey was to have at least 7 years of work experience in the specialty. The number of respondents in the group ranged from 6 to 12 , which met the requirements for achieving the conditions of permissible error of expert analysis of $5 \%(p=0.05)$, when the expert group must include at least 6 experts [31, p. 766].

The respondents were represented by doctors of communal medical enterprises that provide medical care during the COVID-19 outbreak. In particular, these were primary care physicians - general practitioners of family medicine (6 questionnaires), specialists of polyclinics (12), physicians of therapeutic hospitals (12) and surgeons of surgical hospitals (12), maternity hospital doctors (6), doctors of infectious diseases hospitals (6) and doctors of emergency and disaster medicine centres (6) - a total of 60 respondents. 
The questions are grouped into three groups: the first is the respondents' awareness of regulatory and administrative information on labour safety, in particular during the COVID-19 outbreak; the second - their assessment of the state of labour safety at a particular medical institution during the COVID-19 outbreak; third - proposals from respondents to improve the provision of PPE and other safety equipment for health workers in the institutions where they work.

The analysis of the first group of questions showed that knowledge of the legal norm, which provides the right of an employee to refuse to perform professional duties in cases of dangerous working conditions (Article 153 of the Labour Code of Ukraine), showed $50 \%$ of family doctors and specialists, most have more than 10 years of experience. Respondents of other groups did not show awareness of the existence of Art. 153 of the Labour Code of Ukraine. Thus, out of the total number of respondents (60), only 9 specialists provided a positive answer to the question, which is $15 \%$ of the total number of respondents. However, almost all respondents in all groups showed knowledge of the CORONAVIRUS DISEASE Standard (COVID-19) and its appendix №6 "Rational use of PPE in COVID-19". Only one person in the group of polyclinic doctors was unfamiliar with it.

The presence of an order or other local act of the medical institution was also indicated by all respondents, except for the above-mentioned doctor who works in the polyclinic. At the same time, all doctors from inpatient care groups (infectious hospitals, therapeutic and surgical departments, maternity hospitals), 50\% of family doctors and doctors of emergency care and disaster medicine, $25 \%$ of doctors working in polyclinics gave a positive assessment of such acts.

A study of the conditions for implementing the requirements of these regulations and administrative documents shows that all respondents from the groups of hospitals and doctors of emergency and disaster medicine centres and polyclinics indicated the availability of instruction on the use of PPE in the provision of medical care during the COVID-19 epidemic. Only two family physicians stated that they were unaware of the existence of the briefing and accordingly did not participate in the event.

Respondents were asked to rate the effectiveness of the briefing on a scale from 1 to 3 , where: 1 - dissatisfied, 2 - neutral, 3 - completely satisfied. Groups of doctors from infectious hospitals and maternity hospitals were completely satisfied with the briefings. Among family physicians and surgeons from among those who were instructed, all gave a score of 2 points: "neutral." Among other respondents, 50\% of therapists, as well as two doctors - a third of the respondents - from the centres of emergency care and disaster medicine, and two - 17\% - from the group of doctors of polyclinics were completely satisfied. Thus, the assessment (neutral) of the briefing was provided by: $50 \%$ of doctors from therapeutic hospitals, two thirds from the number of doctors of emergency care and disaster medicine and $83 \%$ from the number of doctors of polyclinics.

The next series of questions was devoted to the study of the state of real provision of PPE for health workers. The state of provision of personal protective equipment and other means of safety of medical workers in the relevant medical institutions was asked to be rated on a scale from 1 to 3 , where: 1 - dissatisfied, 2 - neutral, 3 - completely satisfied. All respondents from the group of doctors of infectious diseases hospitals and one respondent from the group of doctors of polyclinics were completely satisfied. The vast majority of respondents from other groups gave a score of 2 points - "neutral." The following questions reveal the grounds for this dissatisfaction with the state of PPE provision. Thus, respondents indicated that the personal protective equipment provided did not always correspond to the level of danger. This was noted by: half of the respondents from the groups of doctors of therapeutic and surgical hospitals, family doctors, as well as $75 \%$ of doctors of polyclinics.

An important factor of dissatisfaction is the insufficient number of PPE provided at the expense of the institution itself, as indicated by doctors of all groups, except for employees of infectious diseases hospitals. As a result, $75 \%$ of respondents were forced to provide themselves with PPE at their own expense, and only $25 \%$ of respondents from the therapeutic and surgical groups and maternity hospitals did not do so.

An integrative indicator that allows to draw a conclusion about the conditions and effectiveness of the use of PPE may indicate the presence of an appropriate control system. Its presence was positively indicated by respondents from all groups, except for 3 respondents (25\%) from the group of family doctors and 6 respondents (50\%) from the group of polyclinic doctors. Further research on this issue shows that in family medicine institutions and polyclinics, the heads of structural departments are (in the vast majority) responsible for monitoring the use of PPE and other means of safety, while in other medical enterprises the chief physician or director of the medical enterprise are responsible for that. This fully correlates with the doctors' answers about the existence of an appropriate local order on the organization of control over the use of PPE and other safety equipment and familiarization with it. Those were the groups of family doctors and doctors of polyclinics who pointed out the absence of such an order.

Analysis of doctors' proposals to improve the provision of PPE and other means of safety of health workers showed that those are doctors of family medicine and outpatient care who insist on implementing a full range of proposals included in the questionnaire, namely: a) ensure the use of PPE in accordance with the level of danger; $b$ ) increase the number of PPE and other safety equipment; $c$ ) acquire more convenient PPE and other safety equipment, $\mathrm{d}$ ) provide effective training and regular briefings on the use of PPE and other safety equipment, e) improve the control system for the use of PPE.

At the same time, respondents from other groups chose only a few options, namely: c) acquire more convenient PPE and other safety equipment (100\% of respondents); b) increase the number of PPE and other safety equipment $(80 \%)$; d) provide effective training and regular briefings on the use of PPE and other safety equipment (60\%); a) ensure the use of PPE in accordance with the level of danger $(60 \%)$.

The results of the survey indicate the existing problems in the labour safety of health workers, resulting in their mass infection with COVID-19. This is also pointed out by Chinese scientists J. Wang, M. Zhou, F. Liu, who conducted a survey in Guangdong province and concluded that the causes of infection 
of health workers are: 1) inconsistency of PPE with the threat posed by coronavirus (doctors were not aware of the ways of its penetration, symptoms and negative impact on the body); 2) prolonged contact with a large number of infected, high labour intensity, lack of rest; 3 ) lack of PPE for doctors; 4) low level of training of doctors to counteract a specific virus [2, p. 101].

At the same time, the effectiveness of the use of PPE in the treatment of patients with COVID-19 has been confirmed by numerous scientific studies. To illustrate the importance of the use of PPE in Singapore, a study of case in which 41 healthcare workers had contact with a patient was conducted. After 14 days of self-isolation and several tests, these individuals were confirmed to not have the disease, as they used the necessary PPE. Researchers have concluded that the basis for the protection of healthcare workers from infection is strict observance of hygiene rules and proper use of PPE [32, p. 766].

As rightly remarks M. Paszkowska, it is the state that is responsible for protecting healthcare workers during the pandemic by taking a number of measures, including the issuance of regulations governing the rights and obligations of the subjects of legal relations in the field of medical services. [33, pp. 802]. All international acts and acts of national legislation, acts concerning the provision of the right to safe working conditions for medical workers must contain scientifically substantiated requirements for the protection of medical workers, which, in turn, must be specified in the health care institution.

\section{CONCLUSIONS}

The study proves that doctors' knowledge of their right to safe working conditions is very limited. The healthcare workers are much more aware of the requirements contained in departmental regulations and administrative acts. In this case, it is the Standard of medical care "CORONAVIRUS DISEASE” (COVID-19) and its appendix №6 "Rational use of personal protective equipment (PPE) in case of COVID-19". Despite the fact that in infectious departments and hospitals of surgical and therapeutic profiles, maternity hospitals such work is generally carried out at the appropriate level, the implementation of departmental acts can not be considered sufficient, as in other institutions that provide mass outpatient, specialized outpatient and emergency assistance, the implementation of departmental acts requires persistent and urgent work.

Based on the study, it was found that the shortage of PPE is a mass phenomenon and, as a result, healthcare workers are forced to buy it at their own expense.

The questionnaire also shows some connection with the state of provision of PPE to doctors and the level of organization of such provision. In institutions where the responsibility for this is placed personally on the heads (directors and chief physicians of medical institutions), the level of satisfaction of doctors with the state of provision and use of PPE is much higher than where the heads of departments are responsible for that.

Suggestions from doctors to improve the situation with the provision of PPE during their activities provide grounds for assessing the current state of the organization of this work in a particular medical institution. Particular attention in this area should be paid to medical institutions of family medicine, polyclinics and emergency centres.

The things mentioned above allow us to formulate proposals for the legal support of the system of guaranteeing safe working conditions for medical workers at a particular medical institution. Legal regulation of safe working conditions for medical workers includes: 1) the existence of legislative provisions and departmental, administrative acts on the right of medical workers to safe conditions, in particular during the COVID-19 pandemic; 2) acquaintance of all medical workers of the enterprise with these acts; 3 ) creation of a system that guarantees safe working conditions for medical workers in a particular enterprise by: a) distribution of responsibilities between the heads of medical enterprises, b) issuing orders and other administrative acts on local labour safety, c) acquaintance with such acts of medical workers by systematic training, d) ensuring the proper quality and quantity, as well as adequate convenience of PPE in accordance with existing needs, e) monitoring the use of PPE and the functioning of the entire system. This requires the creation, in particular, of local protocols or technological maps of the use of PPE in each medical institution and the development and approval of relevant results of their use that are safe working conditions standards. In this paper, it is expedient to combine the efforts of medical workers and specialists in the legal provision of safe working conditions, in particular, for medical workers during the COVID-19 pandemic.

\section{REFERENCES}

1. More than 600 nurses die from COVID-19 worldwide. 3 June 2020. URL: https://www.icn.ch/news/more-600-nurses-die-covid-19-worldwide

2. Since the beginning of the pandemic in Ukraine, the diagnosis of COVID-19 has been confirmed in 9,684 medical workers. 16 August 2020. URL: https://www.ukrinform.ua/rubric-society/3082243-zpocatku-pandemii-v-ukraini-na-covid19-zahvorili-majze-10-tisacmedikiv.html

3. Coronavirus, sale a 172 l'elenco dei medici morti da inizio pandemia. 06 luglio 2020. URL: https://www.repubblica.it/cronaca/2020/07/06/ news/coronavirus_sale_a_172_I_elenco_dei_medici_morti_da_ inizio_pandemia-261159772/

4. Spain sees 396 new COVID-19 infections, doctors protest. 13 June 2020. URL: https://www.aa.com.tr/en/europe/spain-sees-396-new-covid19-infections-doctors-protest/1875766

5. Yang Xiong, Lingli Peng Focusing on health-care providers' experiences in the COVID-19 crisis. The Lancet Global health. VOLUME 8, ISSUE 6, E740-E741, JUNE 01, 2020 P. 740-741

6. Infection prevention and control during health care when coronavirus disease (COVID-19) is suspected or confirmed. Interim guidance World Heath Organization. 29 June 2020. URL: https://www.who.int/ publications/i/item/WHO-2019-nCoV-IPC-2020.4

7. Rational use of personal protective equipment for coronavirus disease (COVID-19) and considerations during severe shortages. Interim guidance World Heath Organization. 6 April 2020. URL: https://www. who.int/publications/i/item/rational-use-of-personal-protectiveequipment-for-coronavirus-disease-(covid-19)-and-considerationsduring-severe-shortages 
8. Geneva Declaration of the World Medical Association. 01 September 1948. URL: https://zakon.rada.gov.ua/laws/show/990_001\#Text

9. An international code of medical ethics of the World medical association. 01.10.1983. URL: https://zakon.rada.gov.ua/laws/show/990_002

10. Universal Declaration of Human Rights of the General Assembly of 10 December 1948. URL: https://zakon.rada.gov.ua/laws/ show/995 015\#Text

11. International Covenant on Economic, Social and Cultural Rights. 16 December 1966.URL:https://zakon.rada.gov.ua/laws/show/995_042/ ed19731019\#Text

12. Convention for the Protection of Human Rights and Fundamental Freedoms. Edited on 2 0ctober 2013. URL: https://zakon.rada.gov.ua/ laws/show/995_004\#Text

13. Occupational Safety and Health Convention, 1981, No. 155, approved by the General Conference of the International Labor Organization. 22 June 1981.URL: https://zakon.rada.gov.ua/laws/show/993_050\#Text

14. Directive № $89 / 391$ / EEC of the Council of the EU on the implementation of measures to improve the safety and health of workers at work. June 12, 1989. Edited on October 22, 2008. URL: https://zakon.rada.gov.ua/ laws/show/994_b23\#Text

15. J. Wang, M. Zhou, F. Liu Reasons for healthcare workers becoming infected with novel coronavirus disease 2019 (COVID-19) in China. VOLUME 105, ISSUE 1, P. 100-101.

16. CASE OF Brincat and others v. Malta. Judgment of the European Court of Human Rights, 24 July 2014. URL: http://hudoc.echr.coe.int/ eng $\mathrm{i}=001-145790$

17. CASE OF Vilnes and Others v. Norway. Judgment of the European Court of Human Rights, 5 December 2013. URL: http://hudoc.echr.coe.int/ fre? $\mathrm{i}=001-138597$

18. Zakon Ukrainy Pro okhoronu pratsi, redaktsiia vid 27.12.2019. URL: https://zakon.rada.gov.ua/laws/show/2694-12\#Text

19. Ustawa o zapobieganiu i zwalczaniu zakażeń i chorób zakaźnych z dnia 5 grudnia 2008 r. URL: https://isap.sejm.gov.pl/isap.nsf/download.xsp/ WDU20082341570/U/D20081570Lj.pdf

20. Criminal codes of OSCE participating States Available from: https:// www.legislationline.org/documents/section/criminal-codes

21. Criminal code of Ukraine. Edited from 13.08.2020. URL: https://zakon. rada.gov.ua/laws/show/2341-14\#Text

22. Cour de cassation République française, civile, Chambre civile 2, 11 octobre 2018, 17-18.712. URL: https://g00-gl.su/kb9S6bk

23. Baulin Y. Rohozhyn B. Vyshnevska I. Legal regulation of professional obligations of physician in Ukraine. Wiad Lek 2019, 72, 9 cz II, p. 1839-1843

24. Code of Labor Laws of Ukraine, Edition dated 02.04.2020. URL: https:// zakon.rada.gov.ua/laws/show/322-08\#Text

25. U Greciyi likari protestuvaly cherez nestachu zasobiv indyvidualnogo zaxystu i medychnogo personalu. 7 kvitnya 2020. URL: https://www. eurointegration.com.ua/rus/news/2020/04/7/7108481/(In Ukrainian).

26. U Xarkovi protestuyut medyky shvydkoyi dopomogy. 18 travnya 2020. URL:https://ua.korrespondent.net/city/kharkov/4229734-u-kharkoviprotestuuit-medyky-shvydkoi-dopomohy (In Ukrainian).
27. Reshenie Promyshlennogo rajonnogo suda g. Kursk Rossijskoj Federacii po delu № 2-1026/2017 ot 13 iyulya 2017 goda. URL: https://sudact. ru/regular/doc/eHQ3rLtOWFZR/ (In Russian).

28. Order of the Ministry of Health of Ukraine № 552 dated 25.02.12020 approved the Standard of medical care "Coronavirus disease 2019" URL: https://moz.gov.ua/uploads/3/19072-dn_20200225_552_dod.pdf

29. Gesetz über die Durchführung von Maßnahmen des Arbeitsschutzes zur Verbesserung der Sicherheit und des Gesundheitsschutzes der Beschäftigten bei der Arbeit. 07 August 1996. URL: https://www. gesetze-im-internet.de/arbschg/BJNR124610996.html

30. The Health and Safety at Work etc. Act 1974 (Application outside Great Britain) Order 1995. URL: https://www.legislation.gov.uk/ ukpga/1974/37/contents

31. Lexan V.M., VolchekV.V., Kryachkova L.V., Zayarskyj M.I. Zastosuvannya kolektyvnyx ekspertnyx ocinok za delfijskoyu proceduroyu v socialnomedychnyx doslidzhennyax. Ukrayina. Zdorovya naciyi, 2017. 1(42): 62-68. (In Ukrainian).

32. Kangqi Ng, Beng Hoong Poon, Troy Hai Kiat Puar et al. COVID-19 and the Risk to Health Care Workers: A Case Report. Annals of Internal Medicine. 2 June 2020 Volume 172, Issue 11. P. 766-767.

33. Paszkowska M. Ustawowe obowiązki lekarza w zakresie zapobiegania i zwalczania chorób zakaźnych. Wiad Lek. 2020; 73(4). P. 801-808

\section{ORCID and contributionship:}

Yuriy V. Baulin: 0000-0001-8764-3567 A, D, E, F

Borys A. Rohozhyn: 0000-0002-6007-6985 B, C, D

Inna A. Vyshnevska: 0000-0001-6114-5818 ${ }^{A, B, D}$

\section{Conflict of interest:}

The Authors declare no conflict of interest.

\author{
CORRESPONDING AUTHOR \\ Inna A. Vyshnevska \\ Yaroslav Mudryi National Law University \\ Kharkiv, Ukraine \\ tel: +380951406024 \\ e-mail: innavish12@gmail.com
}

Received: 02.09 .2020

Accepted: 27.11 .2020

A - Work concept and design, B - Data collection and analysis, C - Responsibility for statistical analysis, D-Writing the article, $\mathbf{E}$-Critical review, $\mathbf{F}$ - Final approval of the article 